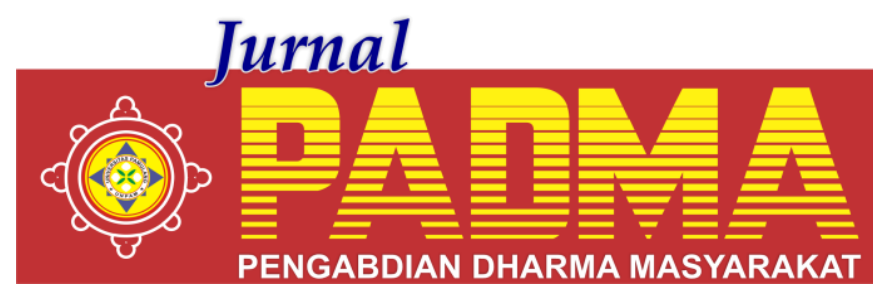

\title{
PELATIHAN PENINGKATAN USAHA MIKRO DALAM MEWUJUDKAN SMART BUSINESS MELALUI SMARTPHONE DI MASA PANDEMI COVID-19
}

\author{
${ }^{1 *}$ Muhammad Sindu Harsofi, ${ }^{2}$ Chaterine Lavenia, ${ }^{3}$ Laila Ardianisa, ${ }^{4}$ Uul Ulyati, \\ ${ }^{5}$ Kristina Marpaung \\ Universitas Pamulang, Tangerang Selatan, Banten, Indonesia \\ *msharsofi27@gmail.com
}

\begin{abstract}
Abstrak
Pelatihan usaha mikro ini untuk meningkatkan ekonomi keluarga dengan memanfaatkan teknologi yang ada, dalam hal ini lebih di khususkan smartphone karna lebih mudah di pelajari dan selalu di pakai dalam kegiatan sehari - hari. Kegiatan ini bertujuan untuk membantu para pelaku usaha mikro dan pemula dalam memanfaatkan teknologi melalui smartphone agar masyarakat setempat dapat meningkatkan ekonomi keluarga dengan tetap menajalankan usahanya meski pada saat pandemi Covid19.
\end{abstract}

\section{Kata Kunci: Usaha Mikro, Online}

\section{Abstract}

This micro business training is to improve the family economy by utilizing existing technology, in this case it is more specifically a smartphone because it is easier to learn and always used in daily activities. This activity aims to help micro and beginner entrepreneurs in utilizing technology via smartphones so that local people can improve the family economy by continuing to run their business even during the Covid-19 pandemic.

Keywords: Micro Business, Online

\section{PENDAHULUAN}

Program pengabdian kepada masyarakat merupakan salah satu program yang wajib dilaksanakan, baik oleh dosen maupun oleh mahasiswa, dengan berlandaskan pada prinsip-prinsip: motivasi pemenuhan kompetensi akademik, jiwa kewirausahaan (entrepreneurship), dan profesional, sehingga dapat menghasilkan program pengabdian kepada masyarakat yang bermutu, relevan, dan sinergis dalam meningkatkan pemberdayaan masyarakat.

Manajemen merupakan salah satu program studi di Universitas Pamulang. Program studi ini memiliki andil dalam mencetak lulusan yang berkarakter serta mampu bersaing di dalam dunia kerja, serta dapat berperan bagi pembangunan Pengabdian kepada masyarakat adalah bentuk Kegiatan pengabdian masyarakat merupakan salah satu Tri Dharma Perguruan Tinggi Selain Pendidikan dan Penelitian, sesuai undang-Undang RI Nomor 20 Tahun 2003 tentang Sistem Pendidikan Nasional, pada Pasal 20 ayat 2 dinyatakan: "Perguruan
Tinggi berkewajiban menyelenggarakan pendidikan, penelitian dan pengabdian masyarakat". Pada Pasal 24 ayat 2 disebutkan:"Perguruan tinggi memiliki otonomi untuk mengelola sendiri lembaganya sebagai pusat penyelenggaraan pendidikan tinggi, penelitian ilmiah, dan pengabdian masyarakat". Pengabdian kepada masyarakat merupakan pelaksa

KEMENTERIAN Komunikasi dan Informatika menyatakan, penggunaan internet di Indonesia sangat tinggi. Hal itu didorong oleh tarif internet yang murah, dan banyaknya jumlah pengguna ponsel pintar mencapai 167 juta orang atau 89\% dari total penduduk Indonesia. Aktivitas yang dilakukan pengguna smartphone yang paling populer adalah browsing internet. Browsing internet yang dimaksud disini adalah mengakses sosial media, streaming musik atau video, hingga mengakses berita.

Di Indonesia sejak bulan Maret 2020 ketika Pemerintah Indonesia mengumumkan kasus pertama virus Corona di Indonesia, Pemerintah sudah menerapkan social 
distancing yang berlanjut dengan physical distancing, dimana sebaiknya interaksi antar manusia dilakukan dalam jarak 1 hingga 2 meter untuk mencegah penyebaran virus. Seiring bertambahnya pasien yang positif terjangkit virus Corona, Pemerintah semakin mengetatkan peraturan agar tidak banyak terjadi interaksi antar manusia. Di beberapa Propinsi seperti DKI Jakarta diberlakukan Pembatasan Sosial Berskala Besar yang membatasi aktivitas warga diluar rumah. Warga harus melakukan kegiatan kesehariannya didalam rumah, seperti bekerja, belajar, dan beribadah di rumah. Pekerjaan banyak dilakukan melalui gadget, termasuk smartphone. Disini kegunaan dari smartphone sangat membantu berbagai aktivitas kegiatan sehari - hari. Dalam perkembangan pemanfaatan teknologi saat ini sangat cepat berkembang, dalam hal ini pengembangan teknologi khususnya smartphone sangat bermanfaat dan selaras dengan perkembangan zaman yang menuntut untuk perubahan cepat dan penyesuaian berbagai aspek bisnis dan juga diberbagai aspek kehidupan dalam masyarakat.

menurut Shelly, et al. (2007) Smartphone adalah telepon yang dapat digunakan untuk mengakses internet, dimana biasanya menyediakan fungsi Personal Digital Assistant (PDA), seperti fungsi kalender, buku agenda, buku alamat, kalkulator, dan note atau catatan. Penggunaan smartphone dalam bisnis dapat memudahkan pelaku usaha dan konsumen dalam melakukan transaksi. Pengertian bisnis secara luas adalah suatu istilah umum yang memberikan gambaran tentang suatu aktivitas dan institusi, dimana memproduksi barang dan jasa dalam kehidupan sehari-hari (Amirullah, 2005).

Usaha mikro merupakan usaha produktif yang memenuhi kriteria Usaha Mikro sebagaimana diatur oleh UndangUndang yang dimiliki orang perorangan dan/atau badan usaha perorangan. Usaha mikro memiliki kriteria yaitu kekayaan bersih yang diperoleh maksimal lima puluh juta rupiah, yang mana tidak termasuk tanah dan bangunan tempat usaha, serta memiliki kekayaan bersih lebih dari lima puluh juta rupiah sampai dengan maksimal lima ratus juta rupiah, juga bukan termasuk tanah dan bangunan tempat usaha (www.bi.go.id).

Saat pembatasan sosial berskala besar, masyarakat diminta untuk tetap tinggal dirumah dan menjalankan aktivitas dari rumah sehingga smartphone menjadi pilihan untuk tetap menjalankan aktivitasnya. Banyaknya aktivitas yang dilakukan melalui smartphone membuka peluang besar untuk para pelaku usaha dalam menjalankan usahanya melalui smartphone. Kecanggihan teknologi membuat para pelaku usaha baik usaha mikro, kecil, maupun menengah melirik bisnis via smartphone ini. Mudahnya berbisnis menggunakan smartphone bukan berati pelaku usaha dapat menyepelekan pembentukan struktur organisasinya. Karena sebelum memulai bisinis, selayaknya dapat direncanakan terlebih dulu bagaimana membentuk struktur organisasi agar bisnis tersebut dapat berjalan efektif. Bisnis menggunakan smartphone juga membutuhkan orang yang tepat untuk menempati posisi yang tepat. Bukan struktur yang gendut atau masif, namun juga jangan sampai kekurangan personil yang menyebabkan overlapping di setiap bagian dalam organisasi.

Kegiatan pemberdayaan masyarakat di situasi pandemi seperti ini diperlukan untuk memberi tambahan pengetahuan bagi masyarakat agar dapat berinovasi dan memanfaatkan teknologi dalam menjalankan usahanya. Seperti Pengabdian Kepada Masyarakat yang dilakukan Soeharjoto et al. (2020) menyimpulkan bahwa setelah dilakukan pengabdian masyarakat, perekonomian masyarakat meningkat karena dapat menambah wawasan mitra dalam mengatasi permodalan dan masalah pemasaran, sehingga termotivasi untuk mengembangkan usahanya.

Topik pembahasan di dalam kegiatan Pengabdian Kepada Masyarakat ini adalah Bagaimana struktur organisasi yang efektif dalam mewujudkan Smart Business usaha mikro pada Smartphone? Kegiatan Pengabdian Kepada Masyarakat (PkM) ini bertujuan untuk memberikan informasi tentang bagaimana struktur organisasi yang efektif dalam mewujudkan Smart Business usaha mikro dengan menggunakan Smartphone. 


\section{METODE}

Pengabdian kepada Masyarakat (PkM) ini dilakukan dengan cara Presentasi langsung pada hari Minggu tanggal 26 April 2021 dimulai pada pukul 10.00 sampai dengan pukul 12.00 WIB dengan jumlah peserta 71 (tujuh puluh satu) orang pesesrta yang terdiri dari para usaha mikro melalui smartphone baik yang sudah memiliki bisnis maupun yang baru ingin memulai bisnis via smartphone. Dimulai dari penjelasan teknologi dan smartphone secara teori, tentang bisnis serta bagaimana struktur dan desain organisasi yang dapat digunakan dalam usaha sederhana, tentang bagaimana memulai bisnis dan mengembangkan bisnis dengan memilih media, desain yang sesuai skala organisasinya, disertai fitur fitur yang bisa dimanfaatkan dalam bisnis menggunakan smartphone. Setelah pemaparan materi oleh para narasumber, selanjutnya dilakukan sesi tanya jawab yang sudah disusun oleh panitia tentang bagaimana memilih dan mendesain struktur organisasi untuk usaha kecil dan menengah. Pada sesi ini, peserta yang aktif berdiskusi bukan hanya yang sudah memiliki usaha. Namun juga ada beberapa peserta yang berminat akan membuka usaha baru yang diawali dengan smartphonenya. Di akhir acara, para peserta mengisi feedback tentang kegiatan Pengabdian kepada Masyarakat ini.

\section{HASIL DAN PEMBAHASAN}

Pengabdian Kepada Masyarakat (PKM) ini dilakukan secara Langsung di salah satu aula yang sudah di mintakan izin untuk presentasi di daerah cirendeu, ciputat timur pada hari Minggu tanggal 26 April 2021 pukul 10.00 sampai dengan pukul 12.00 WIB dengan peserta 71 (Tujuh Puluh Satu) orang yang terdiri dari para peminat usaha mikro.

Usaha mikro adalah badan usaha perorangan yang memiliki kriteria sesuai Undang-Undang (UU) Nomor 20 Tahun 2008 tentang Usaha Mikro, Kecil dan Menengah, yakni: Memiliki aset atau kekayaan bersih hingga Rp 50 juta, tidak termasuk tanah atau bangunan tempat usaha. Dan Omzet penjualan tahunan hingga $\mathrm{Rp} 300$ juta. Usaha mikro yang baru akan dimulai atau sudah berjalan dalam jangka waktu pendek, membutuhkan jenis struktur organisasi atau desain organisasi yang akan di jalankan.
Dengan modal awal yang terbatas, sumber daya manusia yang juga terbatas, pelaku usaha dituntut untuk mengefisienkan modal dan sumber daya yang mereka miliki. Merujuk dari elemen yang mendasari pembentukan struktur organisasi, yang pertama adalah spesialisasi kerja yaitu membagi pekerjaan kedalam beberapa fungsi kerja seperti fungsi pemasaran, fungsi IT, fungsi keuangan, dan fungsi produksi. Elemen selanjutnya adalah menuangkan fungsi kerja tersebut kedalam sebuah departemen. Dalam usaha mikro berbasis smartphone, fungsi yang paling utama adalah fungsi pemasaran yang berbasis IT. Sangat penting mempelajari teknologi yang ada untuk menunjang fungsi pemasaran. Jika pelaku usaha yang akan memulai usaha via smartphone kurang memahami penggunaan teknologi, ada baiknya merekrut orang yang paham dibidang teknologi. Elemen selanjutnya adalah rantai komando. Pada bisnis berbasis smartphone berskala mikro, tidak dibutuhkan rantai komando yang panjang karena personilnya pun belum banyak. Elemen berikutnya adalah rentang kendali. Karena rantai komandonya tidak panjang, maka rentang kendali pun belum banyak dan lebar. Namun seiring bertambahnya tenaga pemasaran, sebaiknya dibuat rentang kendali yang dapat mengakomodir semua lini. Elemen kelima adalah snetralisasi. Dalam bisnis berbasis smartphone, sentralisasi sangat dibutuhkan dalam setiap pengambilan keputusan agar keputusan dapat lebih cepat di ambil. Elemen terakhir adalah formalisasi, dimana dalam membuat usaha sudah dirancang bagaimana prosedur pelaporan, prosedur pengecekan barang, dan sebagainya.

Berdasarkan elemen yang mendasari terbentuknya sebuah struktur organisasi, jenis struktur organisasi yang dapat digunakan oleh pelaku usaha pengguna smartphone berskala mikro adalah kombinasi dari beberapa jenis struktur organisasi. Pelaku usaha dapat menggunakan jenis struktur organisasi berdasarkan fungsi karena skala usaha yang masih mikro. Fungsi-fungsi kerja dibedakan sesuai pekerjaannya seperti fungsi pemasaran, fungsi IT, fungsi produksi, fungsi keuangan. untuk dapat menonjolkan produk yang bersangkutan. Jika pelaku usaha 
memiliki lebih dari satu produk yang akan dipasarkan, setiap orang dengan fungsi kerja yang sama tinggal membedakan produk yang akan dijual. Dengan masukan dari konsep organisasi virtual, pelaku usaha sebaiknya melakukan sentralisasi dalam pengambilan keputusannya. Semua bagian langsung melapor kepada pemilik usaha. Misalnya produk minuman boba memiliki bagian produksi, bagian IT, bagian pemasaran, bagian keuangan yang langsung melapor pada pemilik usaha. Namun jika sumber daya kurang memadai, carilah fungsi kerja yang tidak mampu dijalankan oleh pemilik usaha. Misalnya pemilik usaha mampu membuat minuman boba yang enak, namun kurang paham tentang teknologi yang mampu menampilkan produknya. Maka serahkanlah kepada orang yang lebih paham teknologi untuk dapat membantu bagian pemasaran dan bagian IT sekaligus.

Sementara bagian produksi dan bagian keuangan tetap dipegang pemilik usaha, kedua bagian ini dipegang oleh pemilik dari usaha tersebut agar dalam perhitungan dari proses produksi awal sampai dengan perhitungan biaya - biaya yang nantinya akan menjadi harga dasar produksi dapat diperhitungkan. Perhitungan harga pokok produksi dilakukan agar dapat memperhitungka besaran biaya yang dikeluarkan untuk memproduksi sebuah produk baik produk dalam bentuk barang maupun jasa yang dihasilkan oleh organisasi tersebut. Jika pemilik usaha ingin membuka produk usaha baru dengan tetap berlaku sebagai si empunya resep misalnya produk roti bakar,maka bagian pemasaran sekaligus IT tetap dapat dipegang oleh orang yang sama pada produk yang lain. Tujuan dari di pegang oleh orang yang sama yaitu agar dalam melaksanakan kegiatan pekerjaan baik dan mengetahui seluk beluk dalam proses kerja dari bagian tersebut. Apabila dalam melakukan proses pekerjaan digantikan dengan orang lain dalam hal ini orang baru yang menjalankan pekerjaan tersebut akan mengalami perlambatan dalam prosesnya, karena kalau adanya anggota baru yang menggantikan posisi tersbut maka dalam hal ini harus memberikan training atau pembelajaran dari awal untuk anggota baru tersebut mengetahui proses kerjanya tersebut.
Rentan waktu pembelajaran tersebut sangat menyita waktu dan membuat proses kerja dalam organisasi tersebut, dalam pemaparan yang dilakukan oleh para narasumber menyatakan bahwa dalam perekrutan anggota baru dalam sebuah organisasi harus digandeng dengan anggota yang pernah bekerja dalam bagian tersebut, karena dengan adanya anggota lama yang memberikan pengarahan maka anggota baru dapat beradaptasi secara cepat dan melaksanakan pekerjaan dengan realisasikan pekerjaan yang dibebankan kepada anggota tersebut. Beberapa masukan yang diberikan narasumber akan perkembangan organisasi yang telah menerapkan smartphone sebagai sarana dalam menjalankan kegiatan aktifitas usaha baik memproduksi barang ataupun jasa, beberapa penerapan yang dilakukan oleh organisasi yang telah menggunakan disini para peserta merasa termotivasi untuk menjalankan usaha dengan menggunakan smartphone. Pada awal kegiatan para peserta kurang dapat mengetahui akan manfaat dari smartphone tesebut setelah di berikan pemaparan dan pendampingan terhadap peserta kegiatan pengabdian kepada masyarakat ini sangat membuka wawasan. Sehingga para peserta dapat memilih usaha apa yang cocok terhadap passion maupun kemampuan yang di miliki oleh para pesertanya. Kemampuan yang dimaksud adalah kemampuan dari sisi produk, sumber daya finansial, sumber daya manusia dan lain sebagainya. Dengan melihat kemampuan yang mereka miliki dan passion para peserta dengan berbagai macam golongan, sehingga ide - ide akan bisnis yang akan dibuat beraneka ragam.

\section{PENUTUP}

Bisnis Usaha Mikro dengan modal dibawah 50 juta rupiah memerlukan susunan orang - orang dalam sebuah struktur organisasi yang efektif untuk menjalankan usahanya. Dengan berbisnis melalui smartphone, desain organisasi yang ramping sangat diperlukan. Berdasarkan elemen yang mendasari terbentuknya sebuah struktur organisasi, jenis struktur organisasi yang dapat digunakan oleh pelaku usaha pengguna smartphone berskala mikro adalah kombinasi dari beberapa jenis 
struktur organisasi. Pelaku usaha dapat menggunakan jenis struktur organisasi berdasarkan fungsi karena skala usaha yang masih mikro. Fungsi - fungsi kerja di bedakan sesuai pekerjaannya seperti fungsi pemasaran, fungsi IT, fungsi produksi, fungsi keuangan. untuk dapat menonjolkan produk yang bersangkutan. Jika pelaku usaha memiliki lebih dari satu produk yang akan di pasarkan, setiap orang dengan fungsi kerja yang sama tinggal membedakan produk yang akan dijual. Dengan masukan dari konsep organisasi virtual, pelaku usaha sebaiknya melakukan sentralisasi dalam pengambilan keputusannya.

Semua bagian langsung melapor kepada pemilik usaha. Misalnya produk minuman boba memiliki bagian produksi, bagian IT , bagian pemasaran, bagian keuangan yang langsung melapor pada pemilik usaha. Namun jika sumber daya kurang memadai, carilah fungsi kerja yang tidak mampu dijalankan oleh pemilik usaha. Narasumber memberikan contoh dalam pemaparan Misalnya pemilik usaha mampu membuat minuman boba yang enak, namun kurang paham tentang teknologi yang mampu menampilkan produknya. Maka serahkanlah kepada orang yang lebih paham teknologi untuk dapat membantu bagian pemasaran dan bagian IT sekaligus. Sementara bagian produksi dan bagian keuangan tetap dipegang pemilik usaha. Jika pemilik usaha ingin membuka produk usaha baru dengan tetap berlaku sebagai si empunya resep misalnya produk roti bakar,maka bagian pemasaran sekaligus IT tetap dapat dipegang oleh orang yang sama pada produk yang lain.

Dari hasil kegiatan pengabdian kepada masyarakat ini secara keseluruhan terjadi peningkatan pengetahuan dan pemahaman peserta pelatihan, Sumberdaya Manusia yang terbatas serta faktor usia rata - rata 40 tahun keatas dibutuhkan pendampingan lebih lanjut agar dalam memulai bisnis dengan menggunakan smartphone dapat dilakukan dengan baik serta terarah agar dalam mengaplikasikan kegiatan ini dapat berjalan sesuai dengan yang para peserta harapkan sesuai dengan kemampuan dari masing - masing peserta miliki.

\section{DAFTAR PUSTAKA}

Ajimat, A., Sunarsi, D., \& Sidiq, F. (2020). Berwirausaha Memanfaatkan Media Sosial Pada Daerah Sepatan. ADI Pengabdian Kepada Masyarakat, 1(1), 69-76.

Amirullah. (2005). Pengantar bisnis. Yogyakarta: Graha Ilmu.

Boone, L. E., \& Kurtz, D. I. (2007). Contemporary business (Pengantar bisnis kontemporer). Jakarta: Salemba Empat.

Hasibuan, M. S. (2013). Manajemen Sumber Daya Manusia. Jakarta: PT. Bumi Aksara.

Rahmat, M., Akib, H., Rizal, M., Sakawati, H., \& Aslinda, A. (2021). Hubungan Budaya Organisasi Dengan Inovasi Perusahaan Correlation of Organizational Culture with Company Innovation. JENIUS (Jurnal Ilmiah Manajemen Sumber Daya Manusia), 4(2), 145-152.

Robbins, S. P., \& Judge, T. A. (2013). Organizational behavior. New York: Pearson Prentice Hall. Shelly, G. B., Vermaat, M. E., \& Cashman, T. J. (2007). Discovery computers. Fundamentals, 3th ed.

Williams, B. K., \& Sawyer, S. (2011). Using information technology: a practical introduction to computers and communications, 9the. New York: Mcgraw-Hill.

www.bi.go.id, diunduh tanggal 23 November 2020

www.ekonomi.bisnis.com, diunduh tanggal 23 November 2020 www. galamedia.pikiranrakyat.com.

www.sumeks.co, diunduh tanggal 23 November 2020

https://mediaindonesia.com/humaniora/38 9057/kemenkominfo-89-pendudukindonesia-gunakan-smartphone 